\title{
Drama Translation: Principles and Strategies
}

\section{Suh Joseph Che}

\begin{abstract}
This paper examines the various principles underlying the translation of drama and the strategies that have been outlined by drama translation scholars. It underscores the prescriptive and descriptive attitudes of scholars underlying these principles and strategies. It asserts that the compatibility and integration of translated plays in the receiving culture are at the heart of the principles of drama translation and the strategies outlined. It argues and demonstrates that scholars who are preoccupied with the fate of the translated drama text in the receiving culture solely from the stand-point of its acculturation and integration in that culture are rather restrictive in their approach.
\end{abstract}

Translators of the literary genre of drama, and drama translation scholars have suggested various ways in which drama translation should or could be effected and how the attendant problems should or could be tackled. The various ways suggested can be broadly classified into two main categories: principles and strategies.

Principles could simply be defined here as guiding rules for the drama translator's translational behaviour or action. These principles will be examined from a historical perspective for the 
period spanning the last four decades and only the most representative scholars are examined.

In the sixties, in an article entitled "Some Practical Considerations Concerning Dramatic Translation", Hamberg (1969:91-94) outlined certain principles for the drama translator. He says,

"Drama is action [...] and in translating for the radio, television and the theatre it is important to realize what the dramatic theoreticians above all demand from the spoken line. It must characterize the speaker and thus seem genuine; it must characterize time and place as well as social class; it must not be ambiguous; and it should have been given or one should be able to give it the right emphasis so that it leads the attention of the audience in the desired direction. [...] It goes without saying that an easy and natural dialogue is of paramount importance in a dramatic translation, otherwise the actors have to struggle with lines which sound unnatural and stilted. [...] Even where the author does not indicate in brackets how a line is to be spoken, the translator as well as the stage manager must be able to know how. [...] A translator must be especially careful with entrance lines and exits." [Emphasis in italics is mine.]

Following suit in the seventies, Gravier (1973:41-43) in his article "La traduction des textes dramatiques" states that

"Le traducteur ne doit pas oublier non plus que le texte dramatique, débité à la vitesse normale de la parole, n'est capté qu'une seule fois par le spectateur. [...] Chaque allusion doit être transparente, [...] Il faut éviter les tournures grammaticales qui tombent en désuétude (par exemple: les verbes au passé simple) et, presque partout les questions présentées sous forme d'inversion sont difficilement acceptables. La proposition énonciative 
directe suivie d'un point d'interrogation qui se traduira par une intonation appropriée, dans la bouche du comédien, est, dans presque tous les cas, à préférer. De même on proscrira, bien entendu, toute traduction mot à mot qui déclencherait une crise de fou rire chez les spectateurs. [...] Que le traducteur des textes dramatiques regarde un peu à ce qui se passe au cinéma. Le doublage des films n'est rendu possible que par une minutieuse étude des mouvements que font les lèvres des acteurs, quand ils prononcent les répliques originales." [The translator must not also forget that the words of the play text when spoken at normal speed are captured only once by the audience. [...] Each allusion must be transparent, [...] Archaic grammatical turns must be avoided (for example: verbs in the preterite) and, in almost all instances inverted question forms are hardly acceptable. A direct statement followed by a question mark which should be pronounced by the actor using the appropriate intonation is to be preferred in virtually all cases. Similarly, any word-for-word translation likely to provoke the giggles in the audience must obviously be proscribed. [...] The drama translator should pay some attention to what takes place in the cinema. Dubbing of films is only possible through a very careful study of the movements of the actors' lips when they pronounce the lines of the original play.] [Emphasis in italics is mine.]

In the eighties Wellwarth (1981: 140-146) outlined a series of principles to be followed by the drama translator, categorically asserting that "there are some guidelines that he must follow". According to him,

"The dramatic translator [...] must have a sense of the rhythm of speech patterns, particularly colloquial ones, as well as the ability to recreate the tension of dramatic situations without falsifying the playwright's intention or losing dramatic credibility within the new context. [...] It is absolutely imperative when translating a play to 
translate it aloud and to listen carefully to-even to savour- the various versions into which every conceivable line can be translated in English. Having done that, he should read his translation aloud to someone totally unacquainted with the play, preferably an actor. [...] What the dramatic translator must watch out for particularly is an excess of sibilants in a sentence, or awkward consonantal clusters that may make a line hard to pronounce rapidly and thus may cause difficulties in sound projection [...] the language must fall easily and familiarly on the ears of the audience." [Emphasis in italics is mine.]

Another representative scholar of the eighties, who has clearly enunciated principles to be followed by the drama translator, is Zuber-Skerritt (1988:485-486). He too asserts that:

"A play written for a performance must be actable and speakable. Therefore, non-verbal and cultural aspects and staging problems have to be taken into consideration. [...] Entfremdung is dealienation of the foreign language by translating it into a language which the author would have used if he/she had lived in the time and place of the target language. There is no doubt that the latter is preferable, if not mandatory, in drama translation for the audience must be familiar with the language in order to understand its meaning immediately."[Emphasis in italics is mine]

From the above review it can be said that on the face of it these principles seem feasible to be followed. However, one may wonder to what extent some of them can be successfully applied in practice by the drama translator, particularly in the case of Wallwarth's principle which states that "it is absolutely imperative when translating a play to translate it aloud and to listen carefully to - even to savour -- the various versions into which virtually every conceivable line can be translated". Furthermore, the principle that the drama translator must watch out particularly for "an excess of 
sibilants in a sentence or awkward consonantal clusters that may make a line hard to pronounce rapidly thereby causing difficulties in sound projection" does not tell the drama translator what to do in cases where certain sound effects are intentionally introduced in the speech of some characters by the author of the play either to portray them, for exotic effects, to preserve local colour or for some other reasons. Besides, it can be argued that the issue of transferring sounds from one language to another could ideally be handled within the framework of principles and guidelines outlined in phonological translation wherein source language (SL) phonology is replaced by equivalent target language (TL) phonology but there are no other replacements except such grammatical or lexical changes as may result accidentally from phonological translation (cf. Catford 1965:22). For example, a plural such as in "pens" may in phonological translation come out as singular "pen" if the target language has no final consonant clusters. We know of course that par excellence phonological translation is practised deliberately by actors and mimics, particularly when they want to assume foreign or regional accents. It could therefore be said that the drama translation principles offer mainly hypothetical solutions. Most of the time they implicitly attribute a global nature to such principles and seem to apply to translations between/among all languages. When one talks of principles it implies that they should not be breached by individual drama translators. However, the reality is that there can hardly be global principles in translation between all languages. Furthermore, in actual translation practice, whether in translating between two different languages or translating the play for different audiences between the same two languages, the drama translator may use non-identical methods or strategies.

Also, the drama translation principles outlined mainly highlight and project to the forefront the aptitudes the translator should possess in order to transfer to the target text the gestic/action and oral/acoustic aspects of the source text thereby relegating to the background the equally important analytical and interpretative 
aptitudes that the drama translator should possess, particularly in the case of the African drama translator. In effect, most African playwrights still use European languages to present or describe the cultural and socio-political experiences of their different countries and villages in which their inspiration and creativity are rooted. Their writings in these European languages could be said to constitute a form of translation from their mother tongues for which there is no corresponding written original but rather only an oral one. The playwrights' texts therefore often carry a double language: the European language and the playwright's mother tongue. The African playwright's special use of language resulting from and reflecting this ambivalent situation is often evident in their plays at various levels (lexical, syntactic, imagery, proverbs, dialogue, rhetorical and other stylistic devices). All this of course has an effect on the translation of the plays as the playwright's indigenous thought patterns and linguistic features in the source text would require that the translator analyses and interprets them appropriately in order to transfer them adequately to the target text.

Another observation with respect to drama translation principles highlighted above is their prescriptive nature. This is very evident from and illustrated by the abundant use of words and expressions (highlighted in italics by me in the various passages quoted above) that carry an injunctive and imperative tone and which converge to give the principles a rather heavily prescriptive tone. It is probably as a result of observation by scholars that these translation principles are rather theoretical in nature and are not often readily applicable in concrete situations that they have found it necessary to direct their investigations in another direction, that of strategies which are effectively used by the practising translator in given circumstances. The most prominent of these strategies are examined below.

As from the nineties, drama translation scholars began to examine the phenomenon of drama translation from the viewpoint of 
a different paradigm, that of strategies rather than principles. Contrary to the purely theoretical and prescriptive approach that characterized drama translation principles, their approach is pragmatic and descriptive, examining patterns of translational behaviour through a comparative analysis of performed and published translations of plays of given authors. In other words, instead of prescribing what the drama translator should do, they rather identify and highlight through a contrastive analysis of playtexts what does in reality happen when drama is translated. This shift in focus probably came about as a result of the realization by scholars that drama translation principles ought to serve rather as solid guidelines to make strategic decisions for every specific context of situation.

Before proceeding to examine in detail the main drama translation strategies that have been identified and highlighted by drama translation scholars and in order to enable a better conceptualization of the notion of strategy with respect to drama translation, the following definition is hereby proposed. Drama translation strategies may be defined as actions or procedures on the part of the drama translator either to overcome the problems and obstacles in the way of the communicative process in drama through translation or to ensure that the translation fulfils some specific objectives or functions. Drama translation strategies can therefore be said to be goal-oriented lines of action which operate towards solving a local or global problem or achieving a goal. Obviously, the strategies are carried out within the framework of some specified principles although they do not necessarily have to observe all these principles in their operation.

As pointed out by Aaltonen (2000:4), the study of strategies employed in drama translation shows that while some texts follow their sources carefully and translate them in their entirety, others involve degrees of divergence from them through omissions and additions. In this regard, in research carried out involving a 
macrostructural analysis of about 100 target and source text pairs of plays Merino (2000:357-365), for instance, has come up with a useful classification of the texts studied into 'page' and 'stage' translations and has been able to determine the main translation strategies used by the translators. She also discovered that these strategies correlate directly with her dual classification of the texts studied into 'page' and 'stage' translations. For the stage translations the strategies range from deletion, reduction, merging, omission, adaptation, to other manipulations to conform to specific acting fashions. It is worth noting, however, that these strategies identified by Merino are also used in page translations. In page translations the main strategy she identified is a very close (though not literal) translation of the original, such that the target text when compared with its original every utterance/turn of the original has its counterpart in the translation, and this parallelism is found within each utterance/turn at lower syntactic levels. Page translations favour the source culture and try to get the reader closer to the source author and play. Just as in the case of the stage translations above, it is equally worth noting that the strategies for page translations identified and highlighted by Merino (2000) are also used in stage translations. In this regard, it has been clearly demonstrated by scholars how prominent Cameroonian playwright Oyono Mbia's target texts are on the whole very close translations of the originals, heavily favouring the source culture, with the aim of getting the target readers closer to the source author and plays. Despite this, it has also been established beyond doubt that Oyono Mbia's target texts serve both as 'page' and 'stage' translations in the receiving Cameroonian Anglophone culture. Other scholars have also highlighted some or all of the above strategies identified by Merino (2000) and Aaltonen (2000:4) (cf. Moravkova 1993, Upton 2000, Espasa 2000, Kruger 2000).

According to drama translation scholars, these strategies reflect two main opposing trends: foreignization (characteristic of 'page' translations) and domestication (characteristic of 'stage' 
translations). In her research on the manipulation of otherness in translated drama, Aaltonen (1993:27) asserts that "in translation, foreign drama is transplanted into a new environment, and the receiving theatrical system sets the terms on which this is done. A play script must communicate and be intelligible at some level, even if it should deviate from existing norms and conventions".

Similarly, Ladouceur (1995:31) in her study aimed at evolving a descriptive analysis model for the translation of dramatic texts states that:

\begin{abstract}
"Cette étude descriptive de la traduction n'a donc plus pour objet de déterminer une façon idéale de traduire, mais de voir plutôt comment on traduit, à quelles modalités translatives est soumis le texte afin de pouvoir fonctionner dans la langue et la littérature d'accueil comme équivalence d'un texte d'une autre langue, appartenant à une autre littérature. De ce point de vue, toute analyse de la traduction doit nécessairement se rapporter à la fonction assignée à l'oeuvre traduite dans son contexte adoptif. [The objective of this descriptive translation study is no longer to determine an ideal way of translating but rather to see how translation is actually done and to what translation methods the text is subjected in order for it to function in the receiving language and literature as an equivalent of the text in another language and literature. From this point of view, any analysis of the translation must necessarily take into account the function assigned to the translated work in its new context."]
\end{abstract}

For her part, Moravkova (1993:35) in a study of the specific problems of drama translation states that, "chaque oeuvre dramatique se situe par l'intermédiaire de sa traduction, à l'aide du médiateur - le traducteur - dans un contexte culturel nouveau" [with the help of the translator, acting as mediator, each translated play is placed in a new cultural context]. However, contrary to the above target culture-oriented assertions, in the translation of African drama 
for an African readership/audience there is a clear indication of the fact that the translated drama is not uprooted and placed in an entirely new cultural context but rather in a more or less "same" cultural context. In effect, the primary target consumers of the translations are most often African. It can thus be posited that rather than being target-text oriented, translated African drama, and indeed African literature in general, is essentially source-text oriented. Other proponents of the target text/target culture and receptionoriented approach in drama translation include Brisset (1990), Déprats (1990), Bassnett (1991), Lefevere (1992) and Laliberté (1995).

The decision either to "uproot" the play from its original cultural context or to leave it "untouched" definitely clearly tells on the compatibility and integration of the play in the receiving culture. Consequently, it can be asserted without fear of contradiction that the compatibility and integration of translated plays in the receiving culture are at the heart of considerations with regard to the drama translation principles and strategies outlined.

Drama translation practitioners as well as scholars have all along been preoccupied with the fate of the translated drama text in the receiving culture, in other words, by its compatibility and integration in the receiving culture. This is clearly evident in the various manipulations to which the translated text is subjected as testified by the abundant terminology characterizing such manipulation: 'adaptation' 'acculturation', 'rewriting', 'version' 'transplanting', 'naturalizing', 'neutralizing', 'recreation', 'transposition', 're-appropriation', 'assimilation', 'domestication' etc.

Scholars (cf. Aaltonen 2000:53-54) think that considerations of the compatibility and integration of translated drama in the receiving culture play a crucial role in the choice of the text to be translated and the translation strategies used. Concerning the choice 
of texts, they state that foreign plays are selected on the basis of some discursive structures which either needs to be already in line with those in the target society or can be made compatible with them. For instance, foreign plays which represent either empiricist or emotional reality familiar to the target culture are admitted into its theatrical system more easily than those that are not compatible with its way of looking at the world. Both the choice of texts and the adjustments are carried out in the interests of the integration of the foreign play into the aesthetics of the receiving theatre as well as the social discourse of the target society.

With regard to the translation strategies used, Bassnett (1998:93) cites Romy Heylen who has suggested that in drama translation there is a sliding scale of acculturation that runs from one extreme, where no attempt is made to acculturate the source text that may result in the text being perceived as exotic or bizarre, through a middle stage of negotiation and compromise, and finally to the opposite pole of complete acculturation. Brisset (1990:5) however views the situation differently and asserts that drama texts, perhaps more than any other genre are adjusted to their reception and the adjustment is always socially and culturally conditioned. According to her, "drama as an art form is social and based on communal experience. It addresses a group of people in a particular place at a particular time. It grows directly out of a society, its collective imagination and symbolic representations, and its system of ideas and values." Also taking a contrary stand to Heylen, Aaltonen (1993:27) on her part considers that in translation, foreign drama is transplanted into a new environment and the receiving theatrical system sets the terms on which this is done. She argues that the translated play must communicate and be intelligible at some level, even if it should deviate from the existing norms and conventions. For her therefore, "neutralization or naturalization makes the foreign more manageable and homely; it makes it possible for the audience to comprehend what is happening on the stage; it removes the threat". Several years later, she reasserts that "acculturation is 
inevitable in the translation of a playtext and certainly if that written text is seen as one element in the total process that makes up theatre, then it would follow that some degree of acculturation cannot be avoided and is perhaps more visible than with other types of texts" (Aaltonen 1997; and 2000:55). She further states that in order to make foreign texts compatible with other texts in the target system as well as with the reality of the target society, translation can make use of either acculturation or naturalization in an effort to disguise what is perceived as an obstacle to integration. Acculturation is understood to mean "the process which is employed to tone down the Foreign by appropriating the unfamiliar 'reality', and making the integration possible by blurring the borderline between the familiar and the unfamiliar" (Aaltonen 2000:55). In her opinion, the drama translator, like any writer of plays, uses a suitable strategy to bring the discourse of the source text in line with that of the receiving theatrical system and the entire target society and thus guarantees its acceptance and integration.

It may be argued that scholars who are preoccupied with the fate of the translated drama text in the receiving culture solely from the point of view of its acculturation and integration in that culture are rather restrictive in their approach and therefore fail to take into consideration other instances of drama translated and performed for reasons that could be referred to as exotic to simply entertain and inform the target audience about a foreign culture without any attempt to integrate such drama in the receiving culture. Such is the case of Oyono Mbia's plays mentioned above which were translated in Britain, staged in Britain before a British audience and published by Methuen, a British publishing house whose prime objective is to extend the range of plays in print by publishing work which is not yet known but which has already earned a place in the repertoire of the modern theatre (cf. Oyono Mbia 1968). Oyono Mbia's translated plays have been integrated in the Cameroon Anglophone culture, literature and school syllabuses and not those Britain or the United Kingdom. While Oyono Mbia's original plays are rooted in his 
native Cameroonian Bulu tribe and while Cameroon is a bilingual country made up of Francophones and Anglophones, his original plays and their translations are nonetheless rooted in the same Cameroonian culture. Oyono Mbia can thus be broadly described as translating within a mono-cultural background.

There is also the case of the abundant pre- and postindependence literature (drama and other genres alike) by Cameroonian and other African writers which, even though targeting the European colonial intruders, is integrated and is rooted in Cameroonian and African culture. Both original and translated versions of this literature are normally referred to as Cameroonian literature or African literature. This rather militant literature often attacks the colonial regime and satirizes through the eyes of the Cameroonian or African the European intrusion, invasion and interference with the Cameroonian or African traditional society and its customs. Obviously the best way for anyone to get a message successfully across to another is to first capture his attention and interest in depicting the subject matter. And since it is with the colonialist readership/audience in view that these writers write, naturally therefore, the best means to capture the interest of their readers/audience is to depict the foreign Cameroonian/African society with its exotic culture. Their curious target readers/audience, after having enjoyed reading about or watching on stage the way of life of another society different from theirs, and despite their cultural presuppositions, consciously or unconsciously proceed to a second phase by analyzing in what ways actually that society is different from their own. During this probing stage they come face to face with certain realities, that is, the outside/external and adverse factors affecting that society. And again this may naturally lead them into a third phase, that of self questioning and introspection, i.e. would they like their own culture to be interfered with or even completely destroyed? And of course the ultimate question: How would I react if I were in such a situation? The answers to these questions may be varied from reader to reader or from audience to audience but 
chances are that feelings of sympathy (and of remorse as the case may be) would converge towards the affected society and galvanize a change of attitude or policy on the part of the intruder.

Also, when viewed from another perspective, Cameroonian literature in particular and African literature in general is generally considered less developed than Western literatures that have a very long and established oral and written tradition and until recently have continued to serve as creative models for the younger literatures of the African continent.

In the African pre- and post-independence context it seems very unlikely, therefore, that a play written in French with anticolonial motives and targeting a French audience in France would be translated for an English audience in Britain with the objective of acculturating or naturalizing it in order to integrate it in the English literature and culture.

\section{REFERENCES}

Aaltonen, S. (1993) Rewriting the Exotic: The Manipulation of Otherness in Translated Drama. Proceedings of XIII FIT World Congress. London: Institute of Translation and Interpreting.

(1996) Acculturation of the Other: Irish Milieu in Finnish Drama Translation. Target 9 (1).

(2000) Time-Sharing on Stage: Drama Translation in Theatre and Society. Clevedon: Multilingual Matters Ltd.

Bandia, P. (1993) Translation as Culture Transfer: Evidence from African Creative Writing. TTR 6 (2): 55-76. 
Bassnett, S. (1998a). Translation Across Cultures: Language at Work, British Studies in Applied Linguistics 13.

(1998b) Still Trapped in the Labyrinth: Further Reflections on Translation and Theatre in S. Bassnett \& A. Lefevere (Eds), Constructing Cultures: Essays in LiteraryTranslation, Clevedon: Multilingual Matters, 90-108.

S.Bassnett \& A.Lefevere, (Eds), (1998c) The Translation Turn in Cultural Studies. Constructing Cultures: Essays in Literary Translation, Clevedon: Multilingual Matters.

(1991) Translating for the Theatre: The Case Against Performability TTR 4 (1).

(1990) Translating for the Theatre: Textual Complexities. Essays in Poetics 15: 71-84.

(1985) Ways Through the Labyrinth: Strategies and Methods for Translating Theatre Texts. Theo Hermans (ed), The Manipulation of Literature: Studies in Literary Translation,. London: Croom Helm.

(1980) Translation Studies London: Routledge.

(1978) Translating Spatial Poetry: an Examination of Theatre Texts in Performance. , J. Holmes et al, (Eds), Literature and Translation. Louvain: Acco.

Brisset, A. (1998) Le public ET son traducteur: Profil idéologique de la traduction théâtrale au Québec. TTR 1(1). 
(1990). Sociocritique de la traduction-Théâtre et altérité au Québec (1968-1988). Longueuil: Les Editions du Préambule.

Catford, J. C. (1965) A Linguistic Theory of Translation. Oxford: Oxford University Press.

Déprats, J. M. (1990) Traduire, adapter, écrire. Traduire le théâtre. Paris: Actes Sud.

Espasa, E. (2000) Performability in Translation: Speakability? Playability? Or just Saleability?. C-A Upton (ed) Moving Target: Theatre Translation and Cultural Relocation, Manchester: St. Jerome Publishing.

Gravier, M. (1973) La traduction des textes dramatiques. Etudes de Linguistique Appliquée: Exégèse et Traduction. Paris: Didier.

Hamberg, L. (1969) Some Practical Considerations Concerning Dramatic Translation. Babel 15 (2).

Kruger, A. (2000) Lexical Cohesion and Register Variation in Translation, The Merchant of Vernice in Afrikaans. Unpublished D. Litt et Phil. Thesis. Pretoria: University of South Africa.

Ladouceur, L. (1995) Normes, Fonctions et Traduction Théâtrale. Meta 40 (1).

Laliberté, M. (1995) La problématique de la traduction théâtrale et de l'adaptation au Québec. Meta 40 (4).

Lefevere, A. (1992) Translation, Rewriting and the Manipulation of literary Fame. London: Routledge. 
(1970) The Translation of Literature: An Approach. Babel XVI (2).

Merino, R. A. (2000) Drama translation strategies: English-Spanish (1950-1990). Babel 46 (4).

Moravkova, A. (1993) Les problèmes spécifiques de la traduction des drames. Proceedings of XIII FIT World Congress. London: Institute of Translation and Interpreting.

Oyono Mbia, G. (1968) Switch on and Collect, Interview with Robert Waterhouse in The Manchester Guardian.

(1985) Interview with Students with African Literature Specialisation, Students of the Faculty of Letters and Social Sciences. Yaounde: University of Yaounde.

(1964) Trois Prétendants...Un Mari. Yaoundé: Editions Clé.

(1968) Three Suitors: One Husband. London: Methuen and Co. Ltd.

_ (1967). Jusqu’à Nouvel Avis. Yaoundé: Editions Clé (1968) Until Further Notice. London: Methuen and Co. Ltd.

Upton, C-A. (2000) Moving Target: Theatre Translation and Cultural Relocation. Manchester: St. Jerome.

Wellwarth, G. E. (1981) Special Considerations in Drama Translation. Translation Spectrum: Essays in Theory and Practice. Albany: State University of New York Press.

Zuber-Skerritt, O. (1988) Towards a Typology of Literary Translation: Drama Translation Science. Meta 33 (4). 
